\title{
Himalayan misconceptions and distortions: What are the facts?
}

\author{
Himalayan Delusions: Who's kidding who and why - Science at \\ the service of media, politics and the development agencies
}

Jack D Ives

\begin{abstract}
EDITOR'S NOTE:
J ack Ives' article, drawn from his new book Himalayan Perceptions, is a cautionary tale that might almost be read as a gloss on Peter Weingart's "Moment of truth for science" (see page 11-14). Ives begins by recounting the life and times of the "Theory of Himalayan Environmental Degradation," a grossly exaggerated but convenient "theory of everything" that suited almost everybody's agenda - from the media (always hungry for neatly packaged disaster scenarios), to the politicians (happy to point fingers conveniently away from their own failings), to the developers (ready and willing to focus their energies in the pleasant hills of Nepal rather than the steamy lowlands of Bangladesh and India), to the scientists (eager for fame and funding). True to Weingart's prediction, there was a scientific reaction to the alarmist theories: the Mohonk Conference successfully rallied a generation of "montologists" to investigate critically the bases for predictions of Himalayan deforestation and subcontinental flooding. As a result, the theory was effectively debunked. Unfortunately, it seems to rear its head now and then - most notably in China. And, even more unfortunately, there seems to be a ready supply of successor theories. One media favorite is the impending catastrophic collapse of glacial lakes swollen by glaciers retreating in the face of global warming. Let's hope that Weingart's optimism is justified: melting glaciers and glacial lake outburst floods (GLOFs) obviously deserve scientific attention. The question is, will the media and politicians pay any attention at all if researchers predict something less than a super-catastrophe?
\end{abstract}

\section{It is more from carelessness about truth than from intentional lying that there is so much falsehood in the world.} - Samuel Johnson 1778

This paper is a modified version of Chapter 10 of my recently published book: Himalayan Perceptions: Environmental change and the well-being of mountain peoples (Ives 2004). The original chapter title: What are the facts? Misleading perceptions, misconceptions, and distortions, is intended to draw attention to what I regard as one of the major problems facing effective development and the relief of poverty characteristic of much of the Himalayan region. Mistaken, or deliberately constructed self-serving policies have been exacerbated by false or misunderstood reporting and exaggeration since the beginnings of 'foreign aid' shortly after the end of World War II. My discussion is presented to The Himalayan Journal of Sciences because of the on-going urgency and because the book itself, published in hard cover edition in London and New York, has an unfortunately high price such that it will likely find only modest distribution in South and Central Asia.

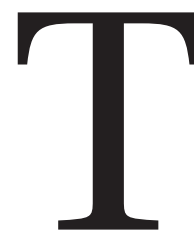

he aim is to address the confusion brought about by a combination of lack of academic rigour in the early stages of the propagation of the myth of Himalayan environmental degradation, aid agency and news media carelessness, and the unsubstantiated basis for some of the policies of regional governments. Thompson and Warburton's (1985) now famous challenge, what are the facts? was originally introduced as part of the refutation of the then widely accepted view that deforestation in the Himalaya by poor farmers was responsible for increased flooding in Gangetic India and Bangladesh. Nevertheless, even with the great increase in research across many disciplines and inter-disciplines since about 1990, their own provocative response to the question remains relevant: 'What would you like the facts to be?'

Central government agencies in India, Thailand, China, and Nepal, for instance, certainly appear to want the 'facts' to support their policies that are frequently based upon the assumption that 'ignorant' mountain minority farmers are devastating the forests and so causing serious downstream environmental and socio-economic damage. The Government of Bhutan largely fabricates its perception of 'truth'. And there has been a continual flow of news media and environmentalist publication to the effect that death and destruction on a large scale are imminent, whether the result of unwise resource extraction by mountain people or due to global forces, such as climate warming. Is it all part of a game? If so, it is a very serious and dangerous game.

This paper examines the larger issues of how Himalayan perceptions have arisen, how many have been misleading, misconceptions, even seemingly deliberate distortions. In contrast, many commentaries and recommendations have been eminently reasonable and have contributed to the eventual inclusion of Chapter 13 in Agenda 21 following the 
1992 Rio de Janeiro Earth Summit. This in turn was the vital turning point that led to the United Nations designation of 2002 as the International Year of Mountains. It is appropriate, therefore, to go back to the origins of the Theory of Himalayan Environmental Degradation and to work forward from there.

\section{The theory of Himalayan environmental degradation}

This topic is introduced here to set the stage for examination of the way in which perceptions of Himalayan development and environmental stability have been, and are being distorted. Other scholars, or developmental practitioners, or environmentalists may select alternate starting points. However, the GTZ-UNESCO conference of December 1974 in Munich can be regarded as the initiation of a worldwide discourse on environmental problems of the Himalaya. The formal topic in Munich was The Development of Mountain Environment and it brought together a diverse group of participants - diverse nationalities, disciplines, and professions. The impacts of the 1972 Stockholm Conference on the Human Environment had only recently been felt. Similarly, the then recent winding down of the International Biological Programme (IBP) had begun to influence the formulation of the UNESCO MAB-Progamme, Project-6, and had demonstrated the applicability of computer modelling.

The Munich participants were presented with a series of well-intentioned, if disturbing, scenarios. Many were based on apparently first-hand experience in the Himalaya, others were derived from experience elsewhere, and yet others depended upon rational thought arising from formal conventional education, or a combination of the above. The participants were alerted informally to GTZ's plans for providing funds to establish an international mountain research and development institution; that it would probably have been headquartered in Tehran because the Shah of Iran of that time had indicated that he would provide many more millions of dollars.

A feeling of dire emergency was generated at the conference, together with a sense of opportunity. Something must be done to save the world's mountains; mountain regions in the developing countries were most seriously at risk; and the Himalaya warranted special attention. A Munich Manifesto was deliberated and unanimously approved. There were suggestions that a 'Club of Munich' should be formed to imitate environmentally the Club of Rome, proceedings were published, and press releases were initiated. Nevertheless, the proceedings (Müller-Hohenstein 1974) were eminently constructive and constrained. A request was made for accentuated mountain research linked to development policy and the creation of a scholarly publication outlet for the results of such research. The need for informing United Nations agencies, national governments, and world opinion at large was underlined. Frank Davidson (in Müller-Hohenstein 1974: 186) urged establishment of an independent mountain research institution with appropriate links to United Nations agencies and universities and, taking cause from the widely recognized contributions of Oceanography, recommended consideration for establishment of mountainology (to become montology-Oxford Dictionary 2002 edition). Very little of the informal discussions about an environmental crisis in the Himalaya appeared in the proceedings. The closest, yet oblique reference appears in the summary report of the proceedings:
But these mountain regions are seriously and increasingly affected by processes of deforestation, soil erosion, improper land use, and poor water management. Overuse of mountain environments has a widening impact on the plains with downstream floods, the siltation of dams and harbours and on the damage of crops and of homesteads.

(Müller-Hohenstein 1974:5)

Thirty years later, following a considerable increase in mountain research (both academic and applied) and much wider recognition of the importance of mountain regions, the general statements emanating from the Munich Conference read as eminently rational. But in terms of the last three decades of melodramatic recounting by the news media of Himalayan deforestation causing catastrophic flooding in Gangetic India and Bangladesh, Eric Eckholm's statement in the Munich proceedings is revealing:

If deforestation in Nepal and Kashmir threatens the survival of three-quarters of a billion people in South Asia, and indirectly will affect the political and economic wellbeing of people in Tokyo, New York, and Munich, then these facts should be in the newspapers every week in all of these countries. But I read several newspapers every day, and have followed the accounts of many major devastating floods over the last few years, and I have discovered that the news accounts never mention deforestation as a cause of the flooding. The collective knowledge of the minds in this room, if distilled in the proper form, would horrify and astound millions of people and hopefully goad them into the needed actions. The question is: How will we help them find out before it's too late.

(my emphasis)

Müller-Hohenstein 1974: 131

Thus it is reasonable to conclude that the Munich Conference of 1974 served indirectly, rather than directly, as the flashpoint for propagating widespread acceptance of the notion of imminent environmental catastrophe in the Himalayan region*. The innumerable literature references to Eckholm's paper in Science (1975) and to his book (1976) show how the assumptions, portrayed with such skill and intellectual appeal in these two publications, dominated mountain environment and development thought over the next 15 years; and the catastrophe discourse has remained highly influential in many areas of government and institutional decision making to the present time.

Despite earlier cautious reaction to the deforestation/ landslide / downstream flooding scenario (Ives 1970) I recall being swept up by the sense of urgency in Munich. Nevertheless, the seeds were sown for eventual publication of the journal Mountain Research and Development in 1981, and for the establishment in 1982 of the International Centre for Integrated Mountain Development (ICIMOD) in Kathmandu.

Following the Munich Conference, however, it appeared that writers, academics, agency personnel, and politicians were seeking to out-perform each other by moving progressively through repetition to hyperbole. No new 'facts' were needed, only the repetition and enlargement of existing 'facts'. Thompson et al. (1986) argued that these 'facts' were precisely what the agency personnel required in seeking to enlarge their development budgets and to expand and prolong their presence in Nepal, long regarded as one of the most attractive locales for 
appointment of expatriate bureaucrats by donor agencies (how that situation has changed when today's events are considered!)

The now notorious World Bank (1979) prediction of total loss of accessible forest cover in Nepal by 2000 was very powerful. The 'State of India's Environment: A Citizen's Report' (1982) spoke with great authority in similar terms, as did the World Resources Institute (1985) and the Asian Development Bank (1982). Likewise, internationally respected foresters and environmentalists raised the spectre of Khumbu forest devastation, perceived as a necessary part of the struggle for establishment of the Sagarmatha National Park. It should be noted, however, that the Khumbu was a special case for it was there that the imminent disaster scenario had unfolded early and independently of the Munich Conference and only later merged with the general demand for mountain forest protection as a prime approach to averting environmental disaster. All of the foregoing were powerful institutional forces that drove the complex of assumptions for which the shorthand term Theory of Himalayan Environmental Degradation was coined.

During the first 10-15 years following the Munich Conference the majority of academic publications concerned with the Himalayan region, or parts of it, both echoed and replenished the news media campaign and the myth of Himalayan environmental degradation became firmly embedded in world opinion. However, after about 1983, first a trickle, and then a flow of academic publications began to discredit the myth although, for the most part, the news media continued on course, as did many of the vested interests of the region. The process of Himalayan environmental discourse and its split into two opposing streams will be illustrated by a selection of short quotations, citations, and comments.

\section{Academic and research publications}

There were innumerable references in scholarly and research publications that advanced and reinforced the Theory:

Eckholm (1975 Science, 189: 764-70: referred to above)

Rieger (in Lall and Moddie 1981:351-76)

These papers provide a parallel discourse to Eckholm (1976) except that Rieger (1981), in particular, develops a series of computer simulations demonstrating relations between population growth, deforestation, soil erosion, and downstream impacts. However, Rieger's approach does foresee a much longer time interval for total elimination of all Himalayan forests.

Ives and Messerli (1981: 229-30-based on an initial reconnaissance for field work in the Kakani area, Nepal):

Loss of soil and loss of agricultural land through gullying and landsliding are occurring more rapidly than the local people with their existing resources can replenish. This is true without considering the deterioration to be anticipated by projecting the current rate of population growth into the future.

To be somewhat redeemed by the following:

It is also believed that involvement of the local people in every planning stage and incorporation of their experience will prove critical.

Karan and Iijima (1985: 81):

One-fourth of the forests of the country has been cut in the past decade. If this trend persists, the remaining forest area may be denuded in another twelve to twenty years.

Karan and Iijima (1985: 84):

The Kulu Valley, formerly a picturesque scene of deodar trees, some forty-five meters high ... is now almost barren.

This statement should be compared with other interpretations of the Kulu landscape that emphasize the excellent degree of preservation of the Kulu Valley forests (reviewed in Ives 2004, Chapter 3: 113).

Myers (1986):

This paper is also a parallel statement to those of Eckholm (1975) and Rieger (1981).

\section{Literature on deforestation in the Khumbu Himal, Nepal}

Blower (1972, cited in Mishra 1973: 2):

... depleting forests of the Khumbu ... since destruction would result in disastrous erosion leading to enormous economic and aesthetic loss to the country.

Lucas et al. (1974) wrote that the members of the New Zealand mission:

... saw too much evidence of incipient erosion to feel other than a sense of deep concern for the future.

Fürer-Haimendorf (1975: 97-8):

Forests in the vicinity of the villages have already been seriously depleted, and particularly near Namche Bazar whole hillsides which were densely forested in 1957 are now bare of tree growth and the villagers have further and further to go to collect dry firewood.

Speechly (1976:2):

. . . forest areas in the proposed Sagarmatha National Park are, as a result of a combination of influences, in a depleted state, such that if present pressure of use is continued, severe environmental damage will result.

Hinrichsen et al. (1983: 204):

... more deforestation [has occurred in the Khumbu] during the past two decades than during the preceding 200 years.

In contradiction to the above, Charles Houston (1982, 1987), as a member of the 1950 Mount Everest reconnaissance from the south, had revisited the Khumbu in 1981. He wrote that, with the exception of a thicket of dwarf juniper at Pheriche there was:

as much or more forest cover than there was in 1950 and I have the pictures to prove it.

\section{International agencies}

World Bank (1979):

Nepal has lost half of its forest cover within a thirty-year period (1950-80) and by AD 2000 no accessible forests will remain.

Asian Development Bank (1982):

... distinct danger that all accessible forests, especially in the Hills, will be eliminated within less than 20 years. (ADB 1982, Vol. 1, p. 12) 
On page 63 of ADB Volume 2, the alarm is somewhat heightened by the prediction of forest elimination within 14 years.

World Resources Institute (1985):

... a few million subsistence hill farmers are undermining the life support of several hundred million people in the plains.

United Nations Environment Programme was reported to have commented on the seriousness of the threat of deforestation in The Bangladesh Observer, Dhaka, 2 June 1990 under the headline Deforestation in the Himalaya Aggravating Floods. The article was reporting on an address to the National Seminar on Environment and Development by Dr Mustafa K. Tolba, Executive Director of UNEP, organized by the Environment and Forestry Ministry, UNDP and UNEP. It quoted Dr Tolba as stating that:

... the chronic deforestation in the Himalayan watersheds was already complicating and compounding seasonal floods in Bangladesh.

And added the comment that 700,000 people died in Bangladesh in 1970 because of flooding.

\section{News media reportage}

Sterling (1976 Atlantic Monthly, 238 [4]: 14-25 - one of the earliest and most melodramatic reports):

Between 1976 and 1986 most of the world's newspapers were predicting imminent disaster in the Himalaya and on the plains of the Ganges and Bramhaputra. The coverage ranged from The Times, London, to almost every local newspaper in the Western World, and in India, Nepal, Pakistan, and China. The coverage extended to leading periodic magazines, such as Newsweek and Atlantic Monthly and the conservationist literature. Television coverage was also extensive world-wide. Examples are restricted to the more recent period following 1986.

Farzend Ahmed in India Today, under the title Bihar Floods: Looking Northwards, 15 October 1987:

Each time north Bihar is devastated by floods, the state Government performs two rituals. It holds neighbouring Nepal responsible and promises to implement a master plan for flood control... Nepal is invariably held guilty because most of the rivers . . . originate there before flowing into the Ganga. The Bihar Government maintains that Nepal's non-cooperation lies at the root of the annual cycle of human misery ... This time the chorus of accusation reached fever pitch when Prime Minister Rajiv Gandhi ... demanded to know what preventative measures had been taken... Predictably, the [response] referred to the hill kingdom's lack of cooperation. The Nepal-bashers also scored a major victory at the Second National Water Resources Council meeting in New Delhi last fortnight. State Irrigation and Power Minister Ramashray Assad Singh managed to have the national water policy draft amended to say that the solution to Bihar's flood problems lay beyond its borders.

Begley et al. 1987 in Newsweek, under the title Trashing the Himalayas - that once fertile region could become a new desert:

Dense alpine forests once covered the lower slopes of Mount Everest, and the Khumbu Valley below the mountain used to blush dark green from its carpet of junipers. But that was the Everest of 1953, when Sir Edmund Hillary and Tenzing Norgay became the first men to conquer the highest peak on earth. Today the forest at Everest's base is 75 percent destroyed, replaced by a jumble of rocks interspersed with lonesome trees. All the Khumbu's junipers have fallen to axes ... The degradation of the Himalayas is not confined to the tall peaks. In Pakistan, India, Nepal and Tibet, deforestation has eroded fertile top-soil from the hills, triggering landslides and clogging rivers and reservoirs with so much silt that they overflow when they reach the plains of the Ganges. . . At the rate trees are being felled for fuel and cropland, the Himalayas will be bald in 25 years ... Although a significant fraction of the erosion stems from nature ... most of the damage is man-made.

\section{New York Times: 9 September 1988:}

United Nations expert Tom Enhault, director of projects in Bangladesh-asserted that the environmental havoc wreaked by the destruction of the Nepalese forests have done the most damage [referring to the flooding of 1987 and 1988]. . . he also blamed over-grazing.

Sunday Star-Bulletin: Honolulu, 11 September 1988: Bangladesh flood disaster blamed on deforestation

Flooding on a massive scale may soon become the norm ... remarkable collapse of the Himalayan ecosystem.

A. Atiq Rahman, director Institute of Advanced Studies, Dhaka, stated 'the main environmental problem is the widespread and growing deforestation of the Indian and Nepalese mountains.' ... B. M. Abbas, Bangladesh's leading authority on water control and for many years Minister of Water Resources said 'For so many years I have told people that trends in the mountains would destroy us.' Hassan Saeed stated that there had been 1,451 deaths and that 700,000 flood refugees had been forced to find shelter in Dhaka.

\section{Dawn: Sunday magazine, Islamabad, 4 October 1992:}

Minister for Environment and Urban Affairs, Anwar Saifullah Khan said 'the destructive power of the floods has increased manifold as a result of deforestation which has been continuing unabated in the Northern Areas of the country.'

\section{Sacramento Bee: Sunday 1 August 1993:}

Bangladesh has renewed demands that India and Nepal agree to control the powerful rivers that flow through their countries. Officials in Bangladesh say the flooding has killed at least 150 people and displaced 7 million people.

World Tibet Network News: Beijing, 28 August 1998, under the headline: Asian Disasters Blamed Partly on Shrinking Forests: Deforestation Leads to Floods:

Floods kill more than 2,000 people along China's Yangtze River and 370 others along the Ganges and Jamuna in Bangladesh... Rain across the region has been much heavier than normal this year, but World Watch Institute President, Lester Brown, said recently that a 'human hand lurks behind the floods. That hand often wields the ax or chain-saw, denuding the highlands that feed Asia's great river systems and sending greater volumes of water and silt to compound the catastrophes downstream. The forests that once absorbed and held huge quantities of monsoon rainfall, which could then percolate slowly into the ground are now largely gone. The result is much greater runoff into the rivers.

Apart from the interspersed explanatory remarks, no further comment will be added to the quotations introduced above, with a single exception. This is because the statement in the 
Islamabad magazine Dawn (4 October 1992), attributed to Environment and Urban Affairs Minister, Anwar Saifullah Khan, is especially out-of-step with reality. The cause of the devastating floods, to which the Minister refers, has been assessed by Hewitt (1993). He was present in Northern Pakistan during the event and was able to obtain many observations on the extent of the damage and subsequently to analyze the records of relevant climate stations throughout the region. The cause was, without doubt, unusual and excessive rainfall. Furthermore, even prior to the opening of the Karakorum Highway and the accelerated and illegal logging, total forest cover of Northern Pakistan was such a minute percentage of total land area that, even if complete removal of trees had been accomplished by 1992, impact on flood magnitude would have been imperceptible.

The political implications of the official statements, however, warrant careful attention. For instance, Bihar and New Delhi authorities and politicians blame Nepal for downstream disasters due to assumed mountain deforestation; Bangladeshi authorities blame India and Nepal; the Chinese government blames the irresponsible and illegal logging by minority peoples in the upper watersheds of the Yangtze. Herein lies part of a possible explanation for institutional adherence to the Theory up to the presence. This will be discussed further below.

\section{How was the academic tide turned?}

Academics undertaking research in the Himalayan region began to reverse the tide of support for the concept of an environmental super-crisis in the early- to mid-1980s. Increasingly since 1989 the Theory of Himalayan Environmental Degradation has come to be regarded as an insupportable myth and today, while some confusion and misunderstanding remains, there is little support within academia for the totality of the notion of Himalayan environmental collapse in the form in which it originated in the 1970s. So, how was the tide turned?

A large part of the explanation is that several research groups and individuals began detailed studies about the same time (late-1970s to1980) and became aware of each other's work. The 'coming together' was greatly facilitated by emergence of the quarterly journal Mountain Research and Development, that in turn led to organization of the Mohonk Conference on the Himalaya-Ganges Problem in May 1986. From that point most of the linkages in the eight-point scenario that was constructed to illustrate the Theory came under increasingly critical investigation. Comparatively little rigorous environmental research had been carried out in the Himalayan region prior to about 1980. The foregoing account of the alarmist discourse in both the academic and popular literature was based upon supposition and emotion that entered policy formulation. It also entered the environmental and development politics of the region and, in turn, encouraged even greater commitment to the 'cause' of addressing Himalayan environmental degradation. Examination of many of the reports prepared for aid agencies and local governments was particularly revealing - successive consultants simply reproduced the conclusions of their predecessors. There were exceptions, although the 'white noise' was almost overwhelming.

For the United Nations University (UNU) research team in Nepal, the tide turned on entering Balami/Chhetri/Tamang villages with Nepalese students and Western university field workers. Johnson, Olson, and Manandhar (1982) quickly learned how well the villagers understood landslide mechanics and witnessed their ability to manage, even to propagate landslides themselves for constructive agricultural use. The research team was able to analyze the complexities of the environmentalsocio-economic situation; year-round research with the subsistence agricultural systems helped to explode the myth, and it became apparent that it had been based upon reports of 'experts', prepared in Kathmandu's best hotels, heavily dependent on earlier reports by other 'experts' also based on Kathmandu hotels but preferably not during the summer monsoon, the peak season for landslides, leeches, and maximum discomfort for field travel.

By 1983 the research progress of the UNU team was sufficiently advanced for a public review of early results to be organized in Kathmandu. This, together with the regular publications scheduled through Mountain Research and Development, became one element in the turning of the tide. There were others equally effective. Most important were the Nepal-Australian Forestry Project and the involvement of the East-West Center, Honolulu. The Australian foresters and their Nepalese graduate students appreciated the 'truth' from living and working with the indigenous mountain farmers (Bajracharya 1983; Mahat et al. 1986a, 1986b, 1987). Hamilton's basic forest ecology led him to attack the notions that forests act as a sponge for excessive rainfall and that 'deforestation' is necessarily bad. He argued that the very term 'deforestation' had been abused to the point of it being reduced to the level of emotion; finally, there was his 'rain on the plain' motif (Ives 2004, Chapter 5:190). Intellectually, one of the most satisfying contributions was Thompson andWarburton's (1985) adaptation of Fürer-Haimdendorf's (1975) 'careful cultivators and adventurous traders' phrase leading to 'uncertainty on a Himalayan scale'. All of these separate strands came together as the 'Mohonk Process' (Thompson 1995; Forsyth 1996).

The answer to the question 'how was the academic tide turned?' is that the very melodrama seems to have aided in prompting the first phase of rigorous research in the Himalaya by scholars who had no restricting vested interests.

But are these the 'facts' and what are the next steps? It appears that as specific myths are identified and explained, modified, or demolished, or used to good effect (Thompson 1995), new ones spring up to take their place.

\section{Some current myths on a Himalayan scale}

A series of examples, or case studies, are introduced to illustrate the problem of misrepresentation. It is unlikely that proof can be obtained to demonstrate a causal relationship between popular reporting and policy formulation, or the reverse. It is also difficult to determine how particular exaggerations are manufactured because the news media as the channel of communication between the field research and sometimes casual observation, and popular presentation is rarely a direct line. Nevertheless, the following examples are offered because the degree of misinformation appears to be both extensive, widespread, and continuing. They are introduced, not so much because of their inherent importance, but as examples that could be multiplied many times over. They could be dismissed as part of a phenomenon that pervades all spheres of world society. Reporting on global warming, the world economy, international terrorism, or almost any disaster has become comparable to the campaign speeches politicians tend to make at election time. It has also been understood for several decades now that 'green' movements have felt compelled to exaggerate in order to compete for attention with the possible bias of well- 
financed campaigns of big business and industry. Regardless, the examples of 'latter-day myths' are set forth because their pervasiveness tends to clutter the sustainable development landscape and perpetuate the Himalayan scale of uncertainty.

\section{The cause of flooding in Bangladesh}

The infamous 1979 World Bank prediction of a nearly treeless Nepal within 20 years has been referred to in different contexts and its re-introduction here may be criticized as out-dated and over-used. Yet it forms a good starting point as a frequently argued explanation for flooding in Bangladesh. Two decades later, in response to the severe flooding of 1998, the Basler Zeitung, amongst numerous major newspapers, published the following on 15 September 1998:

The severe floods in eastern India and Bangladesh are not the result of a natural disaster, but of ruthless exploitation of the forests which has been practiced over many centuries in the Himalayas.

The Canadian Broadcasting Corporation (CBC-TV) produced a documentary for its Newsworld programme on 21 March 2000. The topic was the cyclone of the previous September that caused extensive damage and loss of life in Orissa, India. Amidst dramatic film footage, the commentator warned the viewers that:

... conditions will deteriorate further in the future because the sea level is rising as a result of deforestation in the Himalayas.

Following the Bangladesh flooding of 1998, the news media were awash with hyperbole. Yet the following quotation from the Bangladesh Daily Star should provoke a reflective pause:

Have no fear, the children are enjoying diving in the River Jumuna.

The melodrama is surely recognizable as such, yet the fact remains that the governments of India, China, and Thailand, for instance, have all legislated logging bans on their upper mountain watersheds. Their prime justification is that largescale commercial logging, as well as that of the mountain minority peoples, is causing extensive environmental, economic, and social losses downstream. The linkage with the Three Gorges Dam in China is a prime cause-effect assumption. The danger herein is that, even if the logging bans can be enforced, actual deforestation in the upper watersheds has not been shown scientifically to propagate downstream devastation. Although some kind of control over logging is certainly needed, in the form of consistently applied forest laws and effective forest management, the Government's policy represents an example of trying to solve a problem by confronting an assumed yet unproven cause. It is certain, however, that upstream losses are occurring. However, much of the loss is in the form of considerable hardship placed on the shoulders of the very poor people whose livelihoods depend on the forests and a shift in forest pressure onto the village community forests and the forest reserves of neighbouring countries. Neither can the widespread illegal and legal commercial logging be ignored.

The above commentary is not intended to denigrate the importance of mountain forests since they are vital to the survival of viable mountain agriculture and also have an important aesthetic value. In addition, given good management practices, they are vital for their commercial products.

\section{Meltdown in the Himalaya}

'Meltdown!' is the title of one of four papers published by the New Scientist as part of its celebration of the International Year of Mountains-2002 (Pearce 2002: 44-48). The core of this presentation is an explanation for the undoubted increase in flash flooding that is occurring when glacier lakes in the Himalaya (and elsewhere) break through their end moraine dams to produce destructive mudflows/debris flows/floods for many kilometres downstream. These glacial lake outburst floods (jökulhlaup - Icelandic, or GLOFS) are a topic of widespread current interest (Mool et al. 2001a and b).

There is no question that they represent a serious threat. Nevertheless, Pearce (2002) quotes John Reynolds, an experienced geotechnical consultant, as predicting that:

... the $21^{\text {st }}$ century could see hundreds of millions dead and tens of billions of dollars in damage...

from the outbreak of glacier lakes world-wide, but principally in the Himalaya and Andes. There is also the prediction that the downstream extent of such outburst floods could extend for hundreds of kilometres, cross the borders of Nepal and Bhutan, and cause extensive damage to the large Indian cities on the Ganges flood plain.

There is a factual base for Pearce's reported predictions. Two recent surveys have identified the initiation and growth of about 3,000 such lakes in Bhutan alone (Mool et al. 2001a) and about 2,000 in Nepal (Mool et al. 2001b), of which 44 have been designated as dangerous, although a majority were little more than tiny ponds. Outburst floods that have occurred have barely penetrated more than 50-75 kilometres downstream. There is no intention here, however, to deny that GLOFs are dangerous, nor to imply that serious efforts to mitigate their potential effects are not needed. But it would remain an understatement to suggest that Pearce's reporting represents an exaggeration.

\section{Rolwaling, Nepal, and the threat from Tsho Rolpa glacial lake}

The history of formation and the mechanics of development of potentially dangerous glacial lakes, including Tsho Rolpa, have been described in some detail by several authors (see Ives 2004, Chapter 6). Here emphasis is placed on socio-economic and psychological consequences that arose in 1997 from reactions to a report that Tsho Rolpa was on the brink of a catastrophic outbreak. The discussion is taken from a published blow-by-blow account by Gyawali and Dixit (1997) and personal comments (Gyawali 22 November 2003).

Concerns for the safety of the inhabitants of Rolwaling valley were expressed by the lake survey team in 1996, and the Government of Nepal requested a more detail examination of the end moraine that forms the dam for the expanding lake. This was undertaken in May 1997 by Reynolds Geo-Science Ltd., in collaboration with the Nepal Department of Hydrology and Meteorology (DHM), funded by the British Government. Following the field survey, a seminar was held in Kathmandu to facilitate public and government review. The report presented by the consultants was cited as eminently cautious and responsible. However, following the seminar, oral presentation to the news media appears to have created the impression that 
a catastrophic flood was about to be released momentarily. This produced panic amongst the public and government departments and amongst many of the inhabitants living below the lake all the way down to the frontier with India. The panic prompted the local Member of Parliament to demand immediate government action. It was considered that such a flood would directly affect 4,000 people in 600 households of 18 villages. The warden of the Kosi Tappu Wildlife Reserve in the Terai reported that $175 \mathrm{~km}^{2}$ of the reserve would be destroyed with the loss of 200 wild buffaloes, 400 species of birds, as well as crocodiles, deer, wild boar, snakes, dolphins and other precious animals. It was also contended that the flood would wash away the Kosi Barrage threatening enormous losses in Bihar, India.

The Royal Nepal Airline Corporation (RNAC) suspended flights to the lower area, villagers were evacuated, and workers at the Khimti hydro-electricity project, as well as 90 per cent of the people of Kirnetar, began to evacuate. Police and army posts were set up in the Rolwaling valley.

Many more details of the panic are provided in Gyawali and Dixit (1997) who also estimated considerable personal loss on the part of many people who were induced to leave their homes. Yet the villagers living near Tsho Rolpa, who had observed the seasonal fluctuations in the lake level for years refused to move 'asking the police not to speak nonsense' (Gyawali and Dixit 1997:24).

RNAC resumed its regular flights on 13 July 1997 . By the end of July the flood level of the Tama Kosi, into which the Rolwaling drainage empties, had fallen to almost winter flow conditions and the people who had fled their homes began to return. The results of the affair in Kathmandu included widespread journalistic charges that the rumour of a possible Tsho Rolpa outburst flood had aided expatriate consultants and Department of Hydrology and Meteorology officials to prepare an outrageously expensive proposal for artificial lowering of the lake level for their own financial benefit (Gyawali and Dixit 1997: 33).

The discussion illustrates the severe problem of how authorities should react to potentially lethal mountain hazards that are notoriously difficult to predict with any precision. It underlies the need, not only for extensive survey and monitoring of hazardous mountain phenomena, but also for the establishment of a responsible review and reporting mechanism. In the Tsho Rolpa case by far the most serious losses were caused by the panic reaction to what appears to have been a rumour. Glacial lake outburst floods do occur, as the carefully surveyed case of Dig Tsho of August 1985 illustrated. Following that event, the Government remained lethargic for nearly a decade; by 1997 it appears that the reaction had moved to the opposite extreme - one of panic.

On a related theme The Times of London (21 July 2003), reporting on an international meeting held at the University of Birmingham, noted that 'Himalayan glaciers could vanish within 40 years because of global warming . . .500 million people in countries like India could also be at increased risk of drought and starvation.' Syed Hasnain is quoted as affirming that 'the glaciers of the region [Central Indian Himalaya] could be gone by 2035 .

According to Barry (1992: 45) the average temperature decrease with height (environmental lapse rate) is about $6^{\circ} \mathrm{C} /$ $\mathrm{km}$ in the free atmosphere. The dry adiabatic lapse rate (DALR) is $9.8^{\circ} \mathrm{C} / \mathrm{km}$. If it is assumed that the equilibrium line altitude (comparable with the 'snow line') in the Central Himalaya is about 5,000 masl and it will need to rise above 7,000 $\mathrm{m}$ if all the glaciers are to be eliminated, then the mean temperature increase needed to effect this change would be about $12-18^{\circ} \mathrm{C}$. Given that degree of global warming, summers in Calcutta would be a little uncomfortable.

\section{The Khumbu and Sagarmatha National Park}

As indicated earlier, myths tend to be self-perpetuating. In practice their longevity is often encouraged by vested interests of one form or another. Sagarmatha National Park is perhaps the most likely location in the entire greater Himalayan region for such perpetuation. Conflicting reports and stories here began with Byers's disagreement with the claims for extensive deforestation by Fürer-Haimendorf and the New Zealand foresters as part of the campaign to ensure the gazetting of the world's highest national park (Byers 1986, 1987, 1997; Ives and Messerli 1989: 59-65).

Byers's most recent work indicates the persistence of healthy forests throughout the Sagarmatha National Park area and little change since the 1950s, very long-term indigenous landscape modification, and significant disturbance of the subalpine juniper belt along the approaches to the Mount Everest base camp. The successful reforestation in the vicinity of the park headquarters was certainly an improvement in the park-like landscape although it risks distracting attention from the serious damage in the upper treeline belt. It was with considerable interest, therefore, that Paul Deegan (February 2003) requested review of a manuscript dealing with the dangerous loss of forest cover in the Himalaya, especially in Sagarmatha National Park. The manuscript was sent for critical comment to Alton Byers and Stan Stevens, active current researchers in the Khumbu. The result was a much more balanced account that was submitted by Deegan to Geographical, the London-based monthly magazine. Press deadlines did not permit the author, let alone the informal reviewers, to read the final edited version. The ensuing article was published in the March 2003 issue under an editorially imposed title: Appetite for Destruction. Essential passages accredited to Byers in the original submission had been eliminated and the tone of the conclusions substantially altered. Upon publication, Deegan protested and alerted his informal reviewers to his disappointment. The editor promised to redress the situation by inclusion of the following statement in the June issue of the magazine.

Correction: During the editing process, text was removed from Paul Deegan's article on forest-related issues in Nepal ... that highlighted the difference between healthy forest cover below the treeline in Nepal's Sagarmatha National Park and the clearing that is taking place in the alpine zone. Extensive research by Dr. Alton Byers has shown that not only did the forest cover below the forest treeline remain constant between mid-1950s and the 1980s, but it has increased over the past 20 years.

This article, however, brings another aspect into focus that does involve unfortunate environmental destruction. Fear of Maoist Insurgency activity had prompted Nepalese military personnel to eliminate " $[t]$ housands of young trees around the park headquarters ... to give army personnel clear fields of fire in the event of a rebel attack.' (Deegan 2003:34). Seth Sicroff, who was chairing a conference at Namche, was asked to check the details directly and replied: 'Mendelphu Hill (site of SNP headquarters) has been trashed ... trees cut, foxholes and 
trenches dug, barbed wire everywhere.' (Seth Sicroff pers. comm. 20 May 2003). Nevertheless, Deegan's article, does serve to identify illegal tree felling south of the park boundary by local mountain people as well as provide a firmly documented example from the park itself (Mendelphu Hill) as an act sponsored by government authorities, regardless of whether or not such an act is justifiable in light of the insurgency threat.

The foregoing discussion requires some qualification. Cutting of trees south of the national park boundary in Pharak has been observed for several decades. This has been reported by Stevens (1993, 2003), Ortner (2000), and others. During the 1979 UNU reconnaissance, considerable numbers of porters carrying heavy timbers toward Namche were noted. Similarly, firewood was being carried, not only to the Mount Everest View luxury hotel above Namche, but also for use in the new trekking lodges that were springing up throughout the area. Additionally, illegal cutting was occurring within the park, especially for firewood and construction timber. Nevertheless, this cutting, while likely to be damaging in the long-term if continued unabated, had not been sufficient to cause even local deforestation (i.e. clear cutting), nor to affect the area's hydrological regime and cause accelerated soil erosion. In relation to the pre-1950 landscape changes it was insignificant.

\section{Lake Sarez, Pamir Mountains: Prediction of a flood of 'biblical proportions'}

Lake Sarez began to accumulate behind a massive earthquakeinduced landslide in 1911. By 1998 the upper course of the Murghab River had formed a lake $62 \mathrm{~km}$ long and with a volume of about half that of Lake Geneva. Soviet scientists had been monitoring the lake for several decades but with the collapse of the Soviet Union observations had ceased. Understandably, the government of the newly independent Tajikistan began to express its concern about the possibility of the dam collapsing leading to catastrophic drainage of the lake. Since the lake surface stands at 3,200 masl and the landslide dam is more than $500 \mathrm{~m}$ high, it was eminently reasonable to examine the prospects for a 'worst-case scenario' evaluation. Based on research by staff of the United States Geological Survey on landslides, mudflows, and the dangers of landslide dams (Schuster 1995) the United States Army Corps of Engineers produced a computer simulation. This predicted that if total failure of the dam were to occur (by any measure, a worst case) then the impacts would be profound. According to the computer simulation any total lake outburst would produce a very high speed $(100 \mathrm{~s} \mathrm{~km} / \mathrm{hr}$ ) mudflow varying with the topography of the valley below and the availability of loose slope material, and would eventually extend over 2,000 kilometres to the Aral Sea. Five million lives would be at risk in four different Central Asian countries, together with untold destruction of property. Nevertheless, it is emphasized that this was a computer simulated model of the worst case scenario of the type that is frequently set up in such circumstances to provide a basis for field test and not a vehicle for public alarm.

At the urgent request of the Government of Tajikistan, the UN International Strategy for Disaster Reduction (ISDR), based in Geneva, and theWorld Bank formed a team of experts to investigate the actual nature of the Lake Sarez hazard. With close support, including scientific and military personnel, from the Government of Tajikistan, the team of geophysicists, engineers, geologists, and geographers examined all aspects of the hazard during June 1999 (Alford and Schuster 2000, Alford et al. 2000). In brief, the unanimous conclusion was that the worst-case scenario was such a remote possibility that it could be discounted. Nevertheless, because the mountain slopes above the lake were highly unstable, and also subject to frequent earthquakes, there were inherent secondary hazards. The most likely event, although there was insufficient data available for real-time prediction, would be a large rockfall/landslide hitting the lake surface and generating a seiche wave to over-top the dam. This, in turn, would splash down the steep outer slope of the dam into the Bartang Gorge and imperil the 32 villages that are strung along the floor of the gorge for more than 120 kilometres as far as the confluence with the Pianj River. In view of this, recommendations were made for the installation of fully automatic lake-level monitoring, slope stability monitoring, and advanced warning systems. In addition, a series of 'safe havens' were proposed, to be located above estimated flood levels and stocked with food and supplies for use in an emergency. Installation is proceeding at time of this writing (August 2003).

So far only verifiable facts have been introduced. However, knowledge of the perceived hazard constituted by Lake Sarez was sufficiently widely known that the UN/World Bank team of experts organized a press conference on their return to Geneva. More than 20 eminent news media were represented. Pains were taken to diffuse the relevance of the worst-case scenario; in fact all team members who made presentations emphasized that discussion of such a disaster could be dismissed as wild speculation, if not irresponsible. The facts, as reiterated above, were set forward together with a plea for consideration of the Mountain Tajiks living in the Bartang gorge who already had to contend with a great range of 'normal' natural hazards and, in any event, needed food relief support from the Aga Khan Rural Support Programme to survive there.

It was unfortunate, therefore, that two inflammatory reports appeared (Pearce, New Scientist, 19 June 1999; Burke, The Observer, 20 June 1999) prior to the Geneva press conference. Each article cited as its main source ScottWeber of the 'UN Department for Humanitarian Affairs' and 'who organized the expedition' [to survey the degree of hazard posed by Lake Sarez]. Some of the more inflammatory phrases include: 'Scott Weber said ... they [the research team] had found an enormous disaster waiting to happen.'; 'Five million people could die.'; 'When the natural dam which holds back the water breaks - which experts say could be at any moment - a wave as high as a tower block will blast a trail of destruction a thousand miles through the deserts and plains once crossed by the fabled Silk Road and now covered in farms, fields and cities.'; 'we don't know when it could go, but it could go at any time.' Many details were added to include information on the high seismicity of the region, the recent civil war in Tajikistan, and problems of establishing an early warning system. In contrast, all the news media who were represented at the Geneva press conference reflected the calm assessment of the Lake Sarez team. To underline the exaggerated nature of the reports published by The Observer and The New Scientist the response obtained from an interview (aided by local interpretation) with an elderly widow is reproduced. Her home is located close to the junction of the Bartang and Pianj rivers. When asked to what extent she feared the possibility of a flood from Lake Sarez, she replied:

My parents were living in this house when the 1911 earthquake and landslide occurred and I was born here in 1932. Neither they nor I worried about Lake Sarez. I intend to stay here until I die. If Allah decides that the dam will burst, so be it; but I don't think he will. 
After the mission report was presented, the Government of Tajikistan accepted the recommendations and plans went ahead for design and installation of the monitoring and warning systems. All seemed calm. Then, in early April 2003, an alarm was sounded on a Russian website (www.strog.ru):

In Central Asia an accident on a planetary scale is expected. ... Today, Uzbek scientists have deciphered space images from the Japanese film-making system Aster using the satellite Terra. They discovered that Lake Sarez has overtopped the dam that is now being destroyed as if cut by a giant circular saw.

The ensuing prediction referred to a 100 metre-high mudflow destroying cities for 2,000 kilometres downstream to the Aral Sea with 600,000 to five million lives lost (translated loosely from the Russian by the United States Embassy in Dushanbe). Tense reaction reverberated throughout Central Asia and all the way to Washington DC, as well as to members of the 1999 evaluation team. Sober, authoritative responses calmed the possibility of panic, although the post-1999 Lake Sarez Risk Mitigation Project planned to send a reconnaissance mission to the lake. No recent information has appeared and the very absence of news certifies that there has been no flood 'of biblical proportions' with the loss of millions of lives, and that the April alarm was false.

There is need here for a pause to reflect on the possible events that may have occurred had the 1999 evaluation mission to Lake Sarez not made a responsible assessment. One of the serious risks envisaged at that time was the prospect of governmental over-reaction to the hazard that could prompt a forced, and unnecessary, evacuation of the 32 small villages along the Bartang Gorge together with all the hardship that would entail, even to the collapse of an important, if povertystricken mountain culture (Alford and Schuster 2000: 83-90).

\section{A final anecdote}

This series of anecdotes and commentaries intended to illuminate the regrettable misunderstandings created by the manner in which the Himalayan-Ganges Problem has been reported is brought full circle by returning to the coverage of the serious 1987 and 1988 floods in Bangladesh. Piers Blaikie (pers. comm. 24 June 2003) recalled his interview with the BBC in preparation for the Nine O'clock News programme. When he expressed his conviction that the Theory of Himalayan Environmental Degradation had no factual basis, this caused the interviewer's face to fall. She responded, 'Oh, but I have already had all the upstream/downstream diagrams prepared.' Thus, when the actual news was broadcast the accompanying cartoons showed hectares of trees felled and rising flood waters. All mention of Blaikie's explanation of the socio-economic management of the floods and the lack of any relationship between deforestation in the Himalaya and flooding downstream had been eliminated. He relates that the TV image of his face was seen to jump a little where the section of the film track that explained his opposition to the Theory had been edited out.

\section{Conclusion}

The aim of this discussion has been to highlight the misrepresentation and exaggeration that have been perpetrated for decades and are still being generated today. It is firmly believed that such misrepresentation inhibits urgently required definition of some of the many problems that do beset the region. The single biggest obstruction that dominated the development of thought during the 1970s and 1980s was the widespread assumption that linked increase in mountain rural populations with massive deforestation, soil erosion, and damaging downstream consequences. Some of the real underlying problems that have persisted for decades have been exacerbated by lack of adequate attention or by attempts to solve perceived problems that did not exist, or were of less importance. Although Thompson et al. (1986) expressed doubt that the 'uncertainty' could be dispelled and thus should be accepted as part of the Himalayan scene, it is believed that an attempt should be made to reduce the level of uncertainty as far as possible. Hence the need to ask how the misunderstandings arose and why they have been carried into the present century when, at the same time, the academic perceptions have changed significantly.

This discussion is not intended to minimize the profound complexity of the greater Himalayan region and of its many problems. It would be a disservice to imply that deforestation is not occurring in some specific areas, or that soil depletion and landsliding are unimportant. But these considerations should not be exaggerated and generalized to characterize the entire region, nor should they be articulated to a single simplistic and unsubstantiated cause. This only serves to deflect attention from the extent of poverty, mistreatment of poor minority peoples, and the cruel and self-destructive violent conflicts that are engulfing large parts of the region and so may forestall any attempt at resolution. Nor is it the intention to blame the news media for a large share of the misinformation. Although many elements of the news media are certainly culpable, it is bilateral aid agencies, United Nations institutions, governments, NGOs, and non-rigorous scholars that frequently have failed to show real determination to separate cause and effect, whether intentionally or not. In practice this adds additional weight to the widespread suppression, or at least lack of adequate concern about the well-being of large numbers of poor, and frequently minority, mountain people.

This article is slightly rephrased version of Chapter 10 (What are the facts? Misleading perceptions, misconceptins and distortions) from J ack D Ives's recent book "Himalayan Perceptions: Environmental change and the well-being of mountain peoples", page 211-228, Routledge Taylor and Francis Group, London and New York. Published with the permission of Routledge Taylor and Francis Group.

\section{Note}

* While there had been earlier warnings of perceived environmental degradation in Nepal (Kaith 1960; Skerry et al. 1991), they had not entered the mainstream discourse. In addition, alarm had been expressed concerning the Himalaya and other Asian mountain areas within India, China, and Thailand.

\section{Forcorrespondenceemail:jackives@pigeon.carleton.ca}

\section{References}

Alford D and RL Schuster (eds). 2000. Usoi Landslide Dam and Lake Sarez: An assessment of hazard and risk in the Pamir Mountains, Tajikistan. New York and Geneva: United Nations

Alford D, SF Cunha and Ives JD. 2000. Lake Sarez, Pamir Mountains, Tajikistan: mountain hazards and development assistance. Mountain Research and Development 20(1): 20-23

Asian Development Bank. 1982. Nepal agricultural sector strategy study, 2 
vols, Kathmandu: Asian Development Bank

Bajracharya D. 1983. Fuel, food, or forest? Dilemmas in a Nepali village. World Development 11(12): 1057-1074

Barry RG. 1992. Mountain weather and climate. London and New York: Routledge

Burke J. 1999. Biblical flood poised to drown a nation. The Observer, 20 June 1999. p 25

Byers AC. 1986. A geomorphic study of man-induced soil erosion in the Sagarmatha (Mount Everest) National Park, Khumbu, Nepal. Mountain Research and Development 6(1): 83-87

Byers AC. 1987. An Assessment of landscape change in the Khumbu region of Nepal using repeat photography. Mountain Research and Development 7(1): 77-81

Byers AC. 1997. Landscape change in Sagarmatha (Mt. Everest) National Park, Khumbu, Nepal. Himalayan Research Bulletin XVII(2): 31-41 Deegan P. 2003. Appetite for destruction. Geographical. 2003 March: 32-36

Eckholm E. 1975. The deterioration of mountain environments. Science 189: 764-770

Eckholm E. 1976. Losing ground. Worldwatch Institute, New York: W. W. Norton and Co

Forsyth TJ. 1996. Science myth and knowledge: Testing Himalayan environmental degradation in Northern Thailand. Geoforum 27(3): 375-392

Fürer-Haimendorf C Von. 1975. Himalayan traders: Life in highland Nepal. London: John Murray

Gyawali D and A Dixit. 1997. How distant is Nepali science from Nepali society? Lessons from the 1997 Tsho Rolpa GLOF panic. Water Nepal 5(2): 5-43

Hewitt K. 1993. Torrential rains in the Central Karakorum, 9-10 September, 1992: geomorphic impact and implications for climatic change. Mountain Research and Development 13(4): 371-375

Hinrichsen D, PHC Lucas, B Coburn and BN Upreti. 1983. Saving Sagarmatha. Ambio 11 (5): 274-281

Houston CS. 1982. Return to Everest: A sentimental journey. Summit 28: $14-17$

Houston CS. 1987. Deforestation in Solu Khumbu. Mountain Research and Development. 7(1): 76

Ives JD. 1970. Himalayan Highway. Canadian Geographical Journal 80(1): 26-31

Ives JD and B Messerli. 1981. Mountain hazards mapping in Nepal: Introduction to an applied mountain research project. Mountain Research and Development 1(3-4): 223-230

Ives JD and B Messerli. 1989. The Himalayan Dilemma: Reconciling development and conservation. London and New York: Routledge. $324 \mathrm{p}$

Johnson K, EA Olson and S Manandhar. 1982. Experimental knowledge and response to natural hazards in mountainous Nepal. Mountain Research and Development 2(2): 175-188

Kaith DC. 1960. Forest practices in control of avalanches, floods, and soil erosion in the Himalayan front, Vol. III: Fifth World Forestry Congress Proceedings. Seattle

Karan PP and S Iijima. 1985. Environmental stress in the Himalaya. Geographical Review 75(1): 71-92

Lucas PHC, ND Hardie and RAC Hodder. 1974. Report of the New Zealand Mission on Sagarmatha (Mount Everest) National Park. Kathmandu: Department of National Parks and Wildlife Conservation

Mahat TBS, DM Griffin and KR Shepherd. 1986a. Human impact on some forests of the Middle Hills of Nepal: 1, forestry in the context of the traditional resources of the state. Mountain Research and
Development 6(3): 223-232

Mahat TBS, DM Griffin and KR Shepherd. 1986b. Human impact on some forests of the Middle Hills of Nepal: 2, some major human impacts before 1950 on the forests of Sindhu Palchok and Kabhre Palanchok. Mountain Research and Development 6(4): 325334

Mishra HR. 1973. Conservation in Khumbu: The proposed Mt. Everest National Park. Kathmandu: Preliminary report, Department of National Parks and Wildlife Conservation, Nepal

Mool PK, SR Bajracharya and SP Joshi. 2001a. Inventory of glaciers, glacial lakes and glacial lake outburst floods: Monitoring and early warning systems in the Hindu Kush-Himalayan Region - Nepal Kathmandu: ICIMOD. $363 \mathrm{p}$

Mool PK, D Wangda, SR Bajracharya, K Kunzang, DR Gurung, and SP Joshi. (2001b). Inventory of glaciers, glacial lakes and glacial lake outburst floods: Monitoring and early warning systems in the Hindu Kush-Himalayan Region - Bhutan, Kathmandu: ICIMOD. $227 \mathrm{p}$

Müller-Hohenstein K (ed). 1974. International Workshop on the Development of Mountain Environment, Munich: German Foundation for International Development

Myers N. 1986. Environmental repercussions of deforestation in the Himalayas. Journal of World Forest Resources 2: 63-72

Ortner SB. 2000. Life and Death on Mt. Everest: Sherpas and Himalayan Mountaineering, New Delhi: Oxford University Press

Pearce F. 1991. The rivers that won't be tamed. New Scientist,13 April 1991. p 38-41

Pearce F. 1999. Hell and high water. New Scientist,19 June 1999. p 4

Pearce F. 2002. Meltdown. New Scientist, 2 November 2002. p 44-48

Rieger HC. 1981. Man versus mountain: The destruction of the Himalayan ecosystem. In: Lall JS and AD Moddie (eds), The Himalaya: Aspects of change. Delhi and Calcutta: Oxford University Press. p 351-376

Schuster RL. 1995. Landslide dams - a worldwide phenomenon. Journal of the Japan Landslide Society 31(4): 38-49

Speechley HT. 1978. Proposals for forest management in Sagarmatha (Mt. Everest) National Park. Department of National Parks and Wildlife Conservation, Kathmandu

Sterling C. 1976. Nepal. Atlantic Monthly 238(4): 14-25

Stevens SF. 1993. Claiming the high ground: Sherpas, subsistence and environmental change in the highest Himalaya. Berkeley: University of California Press

Stevens SF. 2003. Tourism and deforestation in the Mt Everest region of Nepal. Geographic Journal 169(3): 255-277

Thompson M. 1995. Policy-making in the face of uncertainty: The Himalayas as unknowns. In: Chapman GP and M Thomson (eds), Water and the Quest for Sustainable Development in the Ganges Valley. London: Mansell. P 25-38

Thompson M and MWarburton. 1985. Uncertainty on a Himalayan scale. Mountain Research and Development 5(2): 115-135

Thompson M, M Warburton and T Hatley. 1986. Uncertainty on a Himalayan Scale. London: Ethnographia

World Bank 1979. Nepal:Development performance and prospects. AWorld Bank Country Study, South Asia Regional Office, World Bank, Washington, DC

World Resources Institute. 1985. Tropical forests: A call to action. Report of an international task force convened by the World Resources Institute, the World Bank and the United Nations Development Programme. Washington, DC:WRI 